\title{
Protein and antigen profiles of Leptospira interrogans serovar Hardjo
}

\author{
Perfil proteico e antigênico da Leptospira interrogans sorovariedade Hardjo
}

\author{
Bárbara Nobre Lafetá ${ }^{\mathrm{E}}$ Elaine Cristina de Castro ${ }^{\mathrm{I}}$ Nivaldo da Silva ${ }^{\mathrm{I}^{*}}$
}

\section{ABSTRACT}

The protein profile of the outer membrane of Leptospira interrogans serovar Hardjo subtype hardjoprajitno associated with the bovine natural immune response was investigated. The outer membrane proteins were extracted utilizing Triton X114 and precipitated with acetone. The protein sample was then resolved by SDS-PAGE and reacted in western blot against sera from a hyperimmune rabbit and from naturally infected bovines. In silver stained gels, 14 protein bands were observed, among which four proteins, with 22, 29, 47 and $63 \mathrm{kDa}$, appeared as major constituents. Western blot tests with hyperimmune rabbit antiserum detected bands corresponding to proteins with $35 ; 27 ; 24 ; 21 ; 17$ and $14 \mathrm{kDa}$, while $32 \mathrm{kDa}$ and $45 \mathrm{kDa}$ proteins were the most immunoreactive with sera from naturally infected bovines.

Key words: Leptospira interrogans, outer membrane protein, hardjoprajitno, immunomodulatory proteins.

\section{RESUMO}

Estudou-se o perfil proteico da membrana externa da Leptospira interrogans sorovariedade Hardjo, amostra hardjoprajitno, associado à resposta imune natural de bovinos infectados. Foram utilizados Triton X114 para a extração das proteínas de membrana externa e acetona para precipitá-las. As proteínas extraídas foram analisadas por SDS-PAGE e western blot contra soro de coelhos hiperimunes e de bovinos naturalmente infectados. Em géis corados com nitrato de prata, 14 bandas proteicas foram identificadas, e quatro dessas bandas, com 22, 29, 47 e 63kDa, foram as mais proeminentes. Os western blots com soro hiperimune de coelho detectaram bandas correspondentes a proteínas com pesos moleculares de 35, 27, 24, 21, 17 e 14kDa, e bandas de 32 e 45kDa destacaram-se nos testes com soros de bovinos naturalmente infectados.
Palavras-chave: Leptospira interrogans, proteína de membrana externa, hardjoprajitno, proteínas imunomodulatórias.

\section{INTRODUCTION}

Leptospirosis caused by Leptospira interrogans is a worldwide zoonosis that predominately afflicts bovine cattle, resulting in spontaneous abortions, embryonic death, infertility and mastitis (ARAÚJO et al., 2005). The most important serovar involved, Hardjo subtype hardjoprajitno, is responsible for significant economic losses in the milk and meat production.

According to serological classification, there are more than 230 Leptospira interrogans serovars (KOIZUMI \& WATANABE, 2004). The strain diversity is due to the structure of lipopolyssacharides (LPS), the major components of the leptospiral outer membrane (OM) (CULLEN et al., 2005). Unlike LPS, most of proteins found in the cell surface are conserved among $\boldsymbol{L}$. interrogans serovars, and these polypeptides can serve as indicators of pathogenicity between different $\boldsymbol{L}$. interrogans serovars or virulence indicators in samples of the same $\boldsymbol{L}$. interrogans serovar (FAINE et al., 1999). Due to the lack of LPSbased vaccines, identification and characterization of protein components of the leptospiral OM is critical for the development of alternative immunoprotection strategies (HAAKE et al., 2000).

IDepartamento de Medicina Veterinária Preventiva, Escola de Veterinária, Universidade Federal de Minas Gerais (UFMG). Av. Antônio Carlos, 6627, São Francisco, 31270-010, Belo Horizonte, MG, Brasil. E-mail: nivaldovet@yahoo.com.br. *Autor para correspondência. 
Studies suggest that the leptospiral OM has a relatively complex protein profile with a broad range of protein molecular weights (HAAKE et al., 1991; HAAKE et al., 2000; CULLEN et al., 2002). The first investigation of the $\boldsymbol{L}$. interrogans OM (NUNESEDUARDS et al., 1985) verified the OM protein composition of six $\mathbf{L}$. interrogans serovars, identifying protein components with 63, 55, 51, 41, 38, 36, 35.5, 33 and $21 \mathrm{kDa}$. According to BROWN et al. (1991), 25, 32, and 35kDa antigens were recognized in western blot of serovar Hardjo subtype hardjoprajitno whole-cell lysates probed with rabbit hyperimmune antisera. More recently, BISWAS et al. (2005) identified 67, 41, 35, 32, 28 , and $22 \mathrm{kDa}$ proteins as major OM components for five different Leptospira serogroups. Western blots with hyperimmune rabbit antisera detected 67, 65, 60, 45, 43, 41 , and $32 \mathrm{kDa}$ common proteins among them. The 32 and $45 \mathrm{kDa}$ were the most immunoreactive proteins using patient sera.

Despite the known relevance of serovar Hardjo subtype hardjoprajitno, only a few studies characterized the protein profile of this bacterium associated to antibody production. The aim of this study was to identify immunoreactive leptospiral proteins from hardjoprajitno that are expressed during the bovine immune response.

\section{MATERIAL AND METHODS}

Bacterial strain and cultivation: Leptospira interrogans serovar Hardjo subtype hardjoprajitno (WHO strain) was grown in three liters of EMJH liquid medium at $30^{\circ} \mathrm{C}$ (ELLINGHAUSEN and MCCULLOUGH, 1965) for at least 1 week. The culture was then centrifuged at $13,000 \mathrm{~g}$ for $10 \mathrm{~min}$ at $4^{\circ} \mathrm{C}$ and the pellet was washed three times in PBS ( $\mathrm{pH} 7.2)$ with $5 \mathrm{mM} \mathrm{MgCl}$. A final concentration of $1.5 \times 10^{11}$ leptospires $\mathrm{ml}^{-1}$ were obtained, as determined by direct cell counting in a Petroff Hausser chamber.

Protein Extraction: The leptospiral OM was extracted according to the technique described by HAAKE et al. (1991) using Triton X114. The proteins extracted that were present in the aqueous and detergent phases were precipitated with 10vol. of acetone in an ice bath for 45min (CUNNINGHAM, 1988). The extracts were then solubilized in $460 \mu \mathrm{L}$ of the final sample buffer (125mM Tris-HCl (pH 6.8), 0.007\% bromophenol blue, $10 \%$ glycerol, $200 \mathrm{mM} \beta$ mercaptoethanol, and 2\% SDS).

Sodium dodecyl sulfate polyacrylamide gel electrophoresis (SDS-PAGE): After protein extraction, all extracts were tested for protein presence by SDSPAGE. A $12 \%(\mathrm{w} / \mathrm{v})$ poliacrylamide gel was used and 7-
$9 \mu \mathrm{L}$ of sample was applied in each lane. The electrophoresis was performed with $150 \mathrm{~V}$, amperes free at $4^{\circ} \mathrm{C}$ in a Mini-PROTEAN II (Bio-Rad) for $60 \mathrm{~min}$. One gel was stained with silver nitrate and the other was reserved to western blot. The software Gel-Proanalyze 3.1 (MediaCybernetics ${ }^{\circledR}$ ) was used to analyze the images and to estimate the molecular weight.

Sera: Serum was raised in rabbits against the serovar Hardjo subtype hardjoprajitno as recommended by the International Committee on Systematic Bacteriology, Sub-Committee on the Taxonomy of Leptospira cited by FAINE et al. (1999). Bovine sera were obtained from 13 animals and tested by MAT (Ryu, 1970). Twelve sera were positive at dilution from 1:100 to 1:1,600.and one was negative and used as control.

Western Blot analysis: Western blot analysis was performed on proteins transferred to nitrocellulose membrane at $100 \mathrm{~V}$, amperes free for one hour in a Sigma Transblot (model: B2157), and blocked with 5\% nonfat dry milk in Tris-buffered saline. Membranes were incubated with hyperimmune rabbit sera at a 1:100 dilution or bovine sera at a 1:50 dilution for one hour at room temperature. They were then washed three times with Tris-buffered saline for ten min. and were probed with a 1:1.000 dilution of rabbit IgG antiserum and bovine antiserum. Membranes were again washed three times with Tris-buffered saline and were exposed to the substrate for peroxidase, DAB, in order to visualize the antigen-antibody complexes. The nitrocellulose membranes were then photographed with a digital camera to estimate the molecular weight of the $\mathrm{OM}$ proteins (OMPs), as described above.

\section{RESULTS AND DISCUSSION}

The overall analysis of the leptospiral OMPs by SDS-PAGE demonstrated the presence of 14 bands, where the bands of 22, 29, 47, and 63kDa proteins were the major constituents (Figure 1, A). In contrast, in western blot with hyperimmune rabbit sera, six stained bands of leptospiral OMPs were determined, and the band sizes were analyzed (Figure 1, B). The stronger bands were 2 (35kDa), r3 (28kDa), r4 (24kDa), r5 (21kDa), r6 (18 kDa), and r8 (14kDa), located in L1 and L2 (Figure $1, \mathrm{~B})$. When the western blot used bovine sera from 13 animals, 12 positive for serovar Hardjo subtype hardjoprajitno and one negative, 2 bands were strongly stained in the positive sera. The software GelProanalyze 3.1 (MediaCybernetics ${ }^{\circledR}$ ) analyzed the images of the positive sera and calculated the molecular weight values. Two bands, $47 \mathrm{kDa}$ and $29 \mathrm{kDa}$, were observed. 


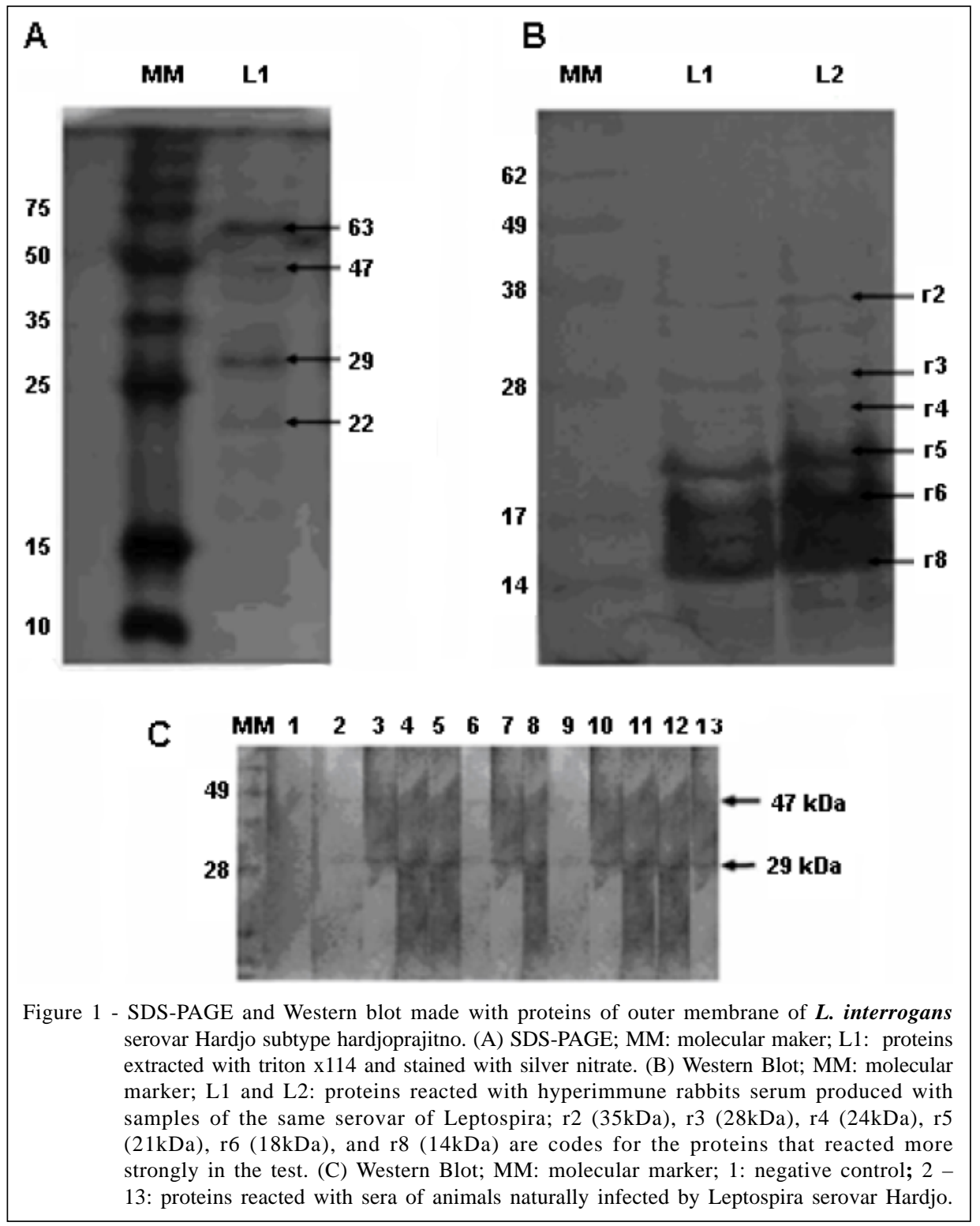

The bacterial surface is the interface between pathogen and host and constitutes the site of interaction with host tissues during infection (CULLEN et al., 2005). The OMPs are the more complexes structure of the cellular surface and are the strongest immunoreactive structure, which makes the molecular detection of these polypeptides a key diagnostic approach. The use of bovine sera in the tests was useful to determine the potential of the OMPs to stimulate the bovine immune system. Through SDS-PAGE (Figure 1, A), the $22 \mathrm{kDa}$ protein appeared as a component of the OM for this $\mathbf{L}$. interrogans serovar, like observed by KOIZUMI \& WATANABE (2003). The polypeptide of $29 \mathrm{kDa}$ founded in serovar Hardjo subtype hardjoprajitno OM represents the main protein component, as observed via SDS-PAGE and in the western blot tested with bovine sera (Figure1, A and C). According to CULLEN et al. (2002), this $29 \mathrm{kDa}$ protein may be a degraded form of LipL32 (molecular weight $32 \mathrm{kDa}$ ). Their immunogenicity was determined during antibody detection tests of naturally infected animals (Figure 1, C) and sera from patients detected a 32kDa polypeptide as the major immunoreactive protein (BISWAS et al., 2005).

A protein with an apparent molecular weight of $47 \mathrm{kDa}$ was observed via SDS-PAGE (Figure 1, A). It is included in a group of proteins that has not yet been described in the leptospire OMP family, and its function 
is still undetermined (CULLEN et al. 2002). The protein found in greater amount, as showed via SDS-PAGE (Figure 1, A) has an apparent molecular mass of 63kDa and was previously described by NUNES-EDWARDS et al. (1985).

In the results of the western blots with rabbit sera (Figure 1, B), two bands ( $35 \mathrm{kDa}$ and $24 \mathrm{kDa}$ ) yielded molecular weights that are very close to those found by BROWN et al. (1991). The slight variation between the molecular weights of these proteins could be explained by differences in result analysis, since those authors did not utilize a software package to calculate the molecular weights of the reactive proteins and only presented estimated values. Therefore, the 35 and $24 \mathrm{kDa}$ bands described in this study, most likely correspond to the 35 and $25 \mathrm{kDa}$ bands, respectively. These proteins appear to develop an important role in immunity of cattle affected by $\boldsymbol{L}$. interrogans serovar Hardjo subtypes hardjobovis and hardjoprajitno. OMPL1 (LipL31), with an estimated molecular weight of $31 \mathrm{kDa}$, undergoes a denaturation process during the extraction and its molecular weight is altered to almost 25kDa (CULLEN et al., 2004). In turn, one may consider that the $24 \mathrm{kDa}$ labeled protein corresponds to LipL31, a trans-membrane protein that is present in different $\boldsymbol{L}$. interrogans serovars. This protein, in association with LipL41 (41kDa), is immunogenic when used during immunization processes in hamsters (HAAKE et al., 1999).

Regarding the minimal differences in molecular weights, the $35 \mathrm{kDa}$ band that was described by BROWN et al. (1991) may be the same 33kDa LPS found in $\boldsymbol{L}$. interrogans serovars via SDS-PAGE by HAAKE et al. (1991). These molecular weight variations must be processed, through software utilization to determine the molecular weights of the proteins extracted, as well as for standardization of the processes for OMPs extraction.

A band that was lightly stained, which is located between bands r2 and r3 (Figure 1, B, L 2), did not have the calculated molecular weight. Even though calculations were not possible, estimation can be performed, by comparison with the bands of the molecular weight marker, which approximate the molecular weight at $32 \mathrm{kDa}$. Most likely, the band is a non-degraded form of LipL32 (BROWN et al., 1991; CULLEN et al., 2002).

There was an extensive background seen in the membrane (Figure 1, B) between the bands r5, r6 and r8, like described by BROWN et al. (1991), It is considered a characteristic in western blot carried out with proteins extracted from $\boldsymbol{L}$. interrogans serogroup Sejroe and reacted with sera from immunized animals with samples of the same serogroup. The background coloration may be a consequence of the large quantity of protein $\mathrm{r} 5(21 \mathrm{kDa})$. Two distinct analyses of the results were probably performed: one considered the middle part of the bands ( $\mathrm{L} 1$ ), and other considered the top of the bands ( $\mathrm{L} \mathrm{2}$ ).

In the membrane (Figure 1, B L 2), r3, with a molecular weight of $36 \mathrm{kDa}$, was intensely stained and correspond to LipL36. According to FAINE et al. (1999), there is a correlation between the expression of LipL36 and the virulence of the sample; This OMP is expressed only under in vitro conditions, after the sample had been cultivated in laboratory for a long time. In this case, the presence of LipL36 is fully consistent with the experimental conditions, since a standard sample was utilized throughout the study, without any contact with the host.

OMP r1, with a molecular weight of $51 \mathrm{kDa}$, was detected only when the tests were made with great amount of antigen (Figure 1, B, L 2). However, HSIEH et al. (2005) described OMP52 with a molecular weight of $53 \mathrm{kDa}$ in $\mathbf{L}$. interrogans, which modulates the interaction between host cells and leptospires during the infection phase and, when the $\boldsymbol{L}$. interrogans is grown in the laboratory, has its expression increased during the stationary phase of cultivation. Because of the similarity of molecular weights of proteins OMP52 and $51 \mathrm{kDa}$ found, none of the tests done here are able to tell us whether they are the same protein. However, one cannot ignore the hypothesis that this may be an isoform of the OMP52 described by HSIEH et al. (2005).

Although the results presented in figure 1, $\mathrm{A}$ and $\mathrm{B}$ are of great importance, the results presented in figure 1, C should be valued as that best represent the reality of $\boldsymbol{L}$. interrogans samples kept from the environment. Based on these results, the proteins with molecular weights of 32 and $45 \mathrm{kDa}$ that were recognized by the bovine immune system are the most important antigens shown. The potential of these antigens must be further investigated during vaccines and diagnostic tests.

\section{ACKNOWLEDGEMENTS}

This work was supported by grant from VALLÉE S/A and CNPq. Thanks o Antônio B. Paula from Leptospiral Lab. of UFMG and Rayane Amaral da Silva Moraes for the text revision

\section{REFERENCES}

ARAÚJO, V.E.M. et al. Freqüência de aglutininas antiLeptospira interrogans em soros sangüíneos de bovinos, em Minas Gerais, de 1980 a 2002. Arquivo Brasileiro de Medicina Veterinária e Zootecnia, v.57, p.430-435, 2005. Available from: <http://www.scielo.br/pdf/abmvz/v57n4/ 26062.pdf $>$. Accessed: aug. 27, 2009. 
BISWAS, D. et al. Comparison of immunoreactive proteins of commonly circulating serogroups of Leptospira in Andaman Islands. Indian Journal Medicine Research, v.121, p.151158, 2005. Available from: http://icmr.nic.in/ijmr/2005/March/ 0302.pdf. Accessed: aug. 27, 2009.

BROWN, J.A. et al. Protein and antigen profiles of prevalent serovars of Leptospira interrogans. Infection and Immunity, v.59, p.1772 1777, 1991. Available from: <http://www.pubmedcentral.nih.gov/ picrender.fcgi?artid=257914\&blobtype=pdf $>$ Accessed: aug. 27, 2009.

CULLEN, P.A. et al. Global analysis of outer proteins from Leptospira interrogans serovar Lai. Infection and Immunity, v.70, p.2311-2318, 2002. Available from: http://iai.asm.org/ cgi/reprint/70/5/2311. Accessed: aug. 27, 2009.

CULLEN, P.A. et al. Outer membrane proteins of pathogenic spirochetes. FEMS Microbiology Letters, v.28, p.291-318, 2004. Available from: http://www.pubmedcentral.nih.gov/ picrender.fcgi artid=2666356\&blobtype=pdf. Accessed: aug. 27, 2009.

CULLEN, P.A. et al. Surfaceome of Leptospira spp. Infection and Immunity, v.73, p.4853-4863, 2005. Available from: < h t t p : / / w w w. p u b m ed c e n t ra l. n i h. g o v / picrender.fcgi ?artid=1201201\&blobtype $=$ pdf $>$. Accessed: aug. 27, 2009.

CUNNINGHAM,T.M. et al. Selective release of the Treponema pallidum outer membrane and associated polypeptides with triton x-114. Journal of Bacteriology, v.170, p.5789-5796, 1988. Available from: <http://www.pubmedcentral.nih.gov/ picrender.fcgi ?artid $=211684 \&$ blobtype $=$ pdf $>$. Accessed: aug. 27, 2009.

ELLINGHAUSEN, Jr. H.C.; MCCULLOUG, W.G. Nutrition of Leptospira pomona and growth of 13 serotypes: fractionation of oleic albumin complex and a medium of bovine albumin and polysorbate 80. American Journal of Veterinary Research, v.26, p.45-51, 1965. Available from: <http://www.garfield.library.upenn.edu/ classics1989/A1989CA26400001.pdf>. Accessed: aug. 27, 2009.

FAINE, S. et al. Leptospira and Leptospirosis. 2.ed. Melbourne: MediSci, 1999. 272p.

HAAKE, D.A. et al. Changes in the surface of Leptospira interrogans serovar grippotyphosa during in vitro cultivation. Infection and Immunity, v.59, p.1131-1140.1991. Available from: <http://www.pubmedcentral.nih.gov/ picrender.fcgi ?artid=258378\&blobtype $=$ pdf $>$. Accessed: aug. 27, 2009.

HAAKE, D.A. et al. Leptospiral outer membrane proteins OmpL1 and lipL41 exhibit synergistic immunoprotection. Infection and Immunity, v.67, p.6572-6582, 1999. Available from: < ht t p / / iai.asm.org/cgi/reprint/6 7/12/ 6572 ? maxtoshow $=\&$ HITS $=10 \&$ hits $=10 \&$ RESULTF O R M A T $=\& \mathrm{fullt}$ e x t $=$ c oli \& s e a r c hi d $=1 \&$ FIRSTINDEX $=2820 \&$ resourcetype $=$ HWFIG. $>$ Accessed: aug. 27, 2009.

HAAKE, D.A. et al. The Leptospiral major outer membrane protein LipL32 is a lipoprotein expressed during mammalian infection. Infection and Immunity, v.68, p.2276-2285, 2000. Available from: <http://iai.asm.org/cgi/reprint/68/4/ 2276 ? $\mathrm{m}$ ax to s h o w $=$ \& H I T S $=10$ \& h i t s $=1$ 0 \& R E S U L T F O R M A T $=\& \mathrm{f} \mathrm{ulltext}=\mathrm{st}$ a p h y lococcal\&searchid=1\&FIRSTINDEX=330\&resourcetype=HWFIG $>$. Accessed: aug. 27, 2009.

HSIEH, W.J. et al. Omp52 is a growth-phase-regulated outer membrane protein of Leptospira santarosai serovar Shermani. FEMS Microbiology Letters, v.243, p.339-345, 2005

KOIZUMI, N. et al. Molecular cloning and characterization of a novel leptospiral lipoprotein with OmpA domain. FEMS Microbiology Letters, v.226, p.215-219, 2003.

KOIZUMI, N. \& WATANABE, H. Leptospiral immunoglobulinlike proteins elicit protective immunite. VACCINE, v. 22, p. 1545-1552, 2004. Available from: <http://www.sciencedirect.com/ science?_ob=ArticleURL\&_udi=B6TD4-4B0NT1H$18 \_$user $=686413 \&$ \& rdoc $=18 \_$fmt $=\&$ \&orig $=$ search \&_sort $=\mathrm{d} \&$. docanchor $=\&$ view $=c \&$ \&searchStrId $=995965959 \&$ \&erunOrigin $=$ google\&_acct $=$ C000037539\&_version $=1 \&$ \&_urlVersion $=0$ \& _userid $=686413 \& \mathrm{md} 5=20 \mathrm{e} 22 \mathrm{c} 2524 \mathrm{ec} 30 \mathrm{c} 56999 \mathrm{~b} 3 \mathrm{~b} 4 \mathrm{f} 5 \mathrm{ed} 3 \mathrm{~b} 3 \mathrm{f}>$. Accessed: aug. 27, 2009. doi: 10.1016/j. vaccine. 2003.10.007

NUNES-EDWARDS, P.L. et al. Identification and characterization of Leptospira interrogans serovar hardjo. Infection and Immunity, v.48, p.492-497, 1985. Available from: <http://www.pubmedcentral.nih.gov/ picrender.fcgi?artid=261355\&blobtype=pdf $>$. Accessed: aug. 27, 2009.

RYU, E. Rapid microscopic agglutination test for Leptospira based on 400X magnification of darkfield examination. Taiwan Journal Medicine Animal, n.17, p.1-9, 1970. 